\title{
A Case of Huge Solitary Fibrous Tumor with Maxillary Sinus Wall Destruction Masquerading as Maxillary Sinus Cancer
}

\author{
Soojeong Choi, Kijeong Lee, Jaehyun Shim, and Sang Hag Lee (iD) \\ Department of Otolaryngology-Head and Neck Surgery, College of Medicine, Korea University, Seoul, Korea \\ 상악골벽의 파괴를 동반하여 상악동 암으로 의심되었던 거대한 고립성 섬유종 1 예 \\ 최수정 · 이기정 · 심재현 · 이상학 \\ 고려대학교 의과대학 이비인후-두경부외과학교실
}

\author{
Received June 8, 2020 \\ Revised September 2, 2020 \\ Accepted September 7, 2020 \\ Address for correspondence \\ Sang Hag Lee, MD \\ Department of Otolaryngology- \\ Head and Neck Surgery, \\ Korea University \\ College of Medicine, \\ 73 Goryeodae-ro, Seongbuk-gu, \\ Seoul 02841, Korea \\ Tel +82-2-920-5486 \\ Fax +82-2-925-5233 \\ E-mail sanghag@kumc.or.kr
}

Solitary fibrous tumors (SFT) are rare fibroblastic mesenchymal neoplasms which are originally described as neoplasms of the pleura originating from the spindle cells. Although it can originate from extrapleural sites including the head and neck, it is exceedingly rare in the sinonasal tract. There has been no reported cases of SFT involving the paranasal sinuses in Korea; however, there was case of a 34-year-old man who presented with persistent left nasal obstruction and watering of the left eye. Imaging by $\mathrm{CT}$ and MRI revealed a large, highly vascular tumor occupying the maxilloethmoidal sinus cavities associated with bony wall destruction, masquerading as maxillary sinus cancer. The tumor mass occupying sinus cavities was removed through endoscopic and Caldwell-Luc approach. Histopathological examination of the tumor was consistent with SFT. We report this case to further insights regarding the diagnosis and management of this rare tumor.

Korean J Otorhinolaryngol-Head Neck Surg 2020;63(12):606-10

\section{서 론}

고립성 섬유종(solitary fibrous tumor)은 중배엽에서 발생 하기 때문에 양성 섬유 중피종(benign fibrous mesothelioma) 혹은 중피하부위 섬유종(submesothelial fibroma)으로 분류 되었다. 그 후 중배엽 세포의 분화없이 흥막이나 복막에서 원 발하기 때문에 현재에는 고립성 섬유종으로 분류되고 있다. ${ }^{1)}$ 흥막 외의 다른 부위에서도 발견되는데 두경부에서는 구강과 안와에서 주로 발견되고 비부비강에서는 매우 드물게 발생한 다. ${ }^{2}$ 비부비강에서는 상대적으로 드물게 발생한다는 점과 외 관적으로 다양한 형태로 관찰되기 때문에 비부비강에서 발생

This is an Open Access article distributed under the terms of the Creative Commons Attribution Non-Commercial License (https://creativecommons.org/licenses/by-nc/4.0) which permits unrestricted non-commercial use, distribution, and reproduction in any medium, provided the original work is properly cited.
하는 다른 중배엽 발생의 종양과 감별진단하기가 어렵다. ${ }^{2)}$

저자들은 좌측 비폐색을 주소로 내원한 환자에서 내시경 검사상 부비강의 종물이 비강의 중·하비갑개를 내측으로 편 위 시킴으로써 비강이 폐쇄되는 소견이 관찰되었고, 부비강 컴퓨터단층촬영에서 상악동과 사골동 골벽의 파괴를 동반 하여 악성종양을 의심하게 된 고립성 섬유종을 치험하였기에 이를 문헌 고찰과 함께 보고하고자 한다.

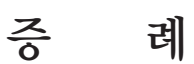

34세 남자가 4달 전부터 시작된 좌측 비폐색으로 내원하였 다. 특이병력 없는 환자로 좌측 비폐색과 좌측 눈물 고임 외에 다른 동반 증상은 없었다. 내시경 검사상 상악동 내 종양이 좌 측 중비갑개와 하비갑개를 비강 내측으로 편위시키는 형태로 
관찰되었다. 경부에서 촉지되는 종물은 없었고, 종물 표면은 정상 점막으로 덮혀 있는 형태로 관찰되었다(Fig. 1).

부비강 전산화단층촬영상 좌측 상악동과 사골동에 조영
증강된 종 양이 확인되었고, 좌측 전사골동, 상악동의 외측 골 벽 및 상악동 내벽의 파괴가 관찰되었으며 중비갑개와 하비갑 개를 비강 내측으로 편위시키는 양상으로 관찰되었다(Fig. 2).
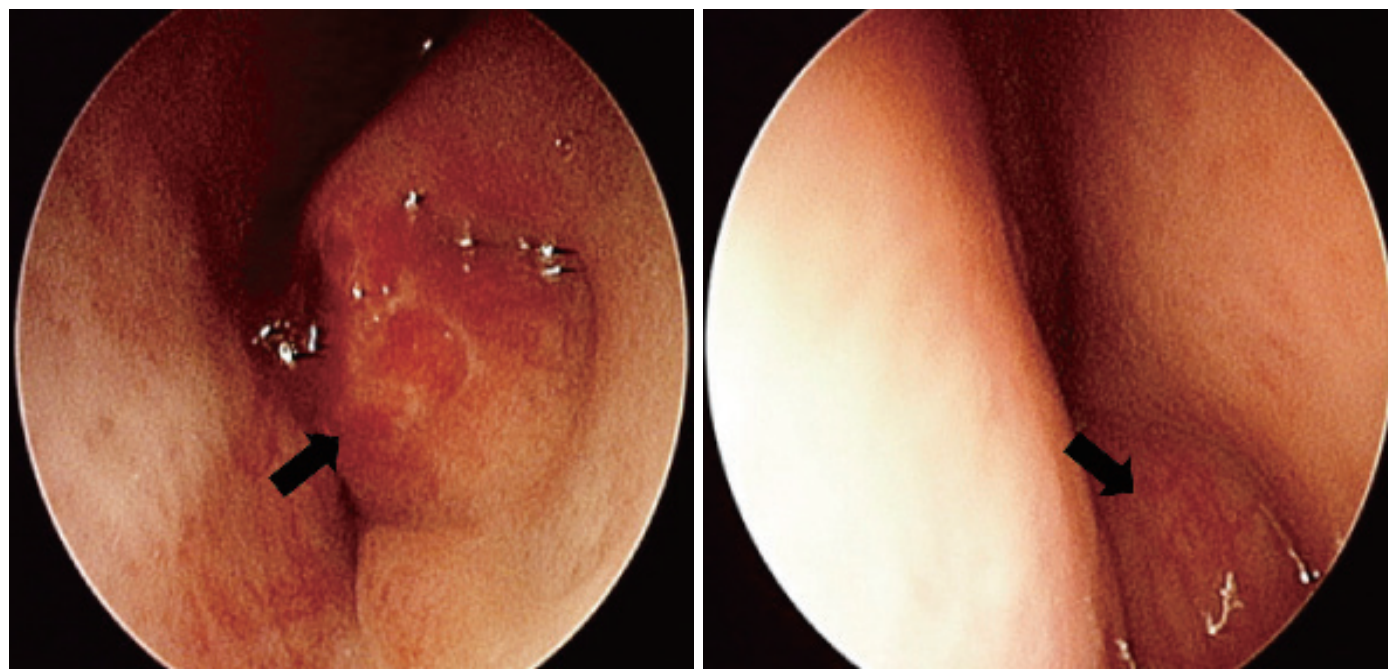

Fig. 1. Endoscopic findings in nasal cavity: inferior and middle turbinate are medially displaced by suspected maxillary tumor which is covered with normal mucosa. Arrow indicates inferior and middle turbinate respectively.
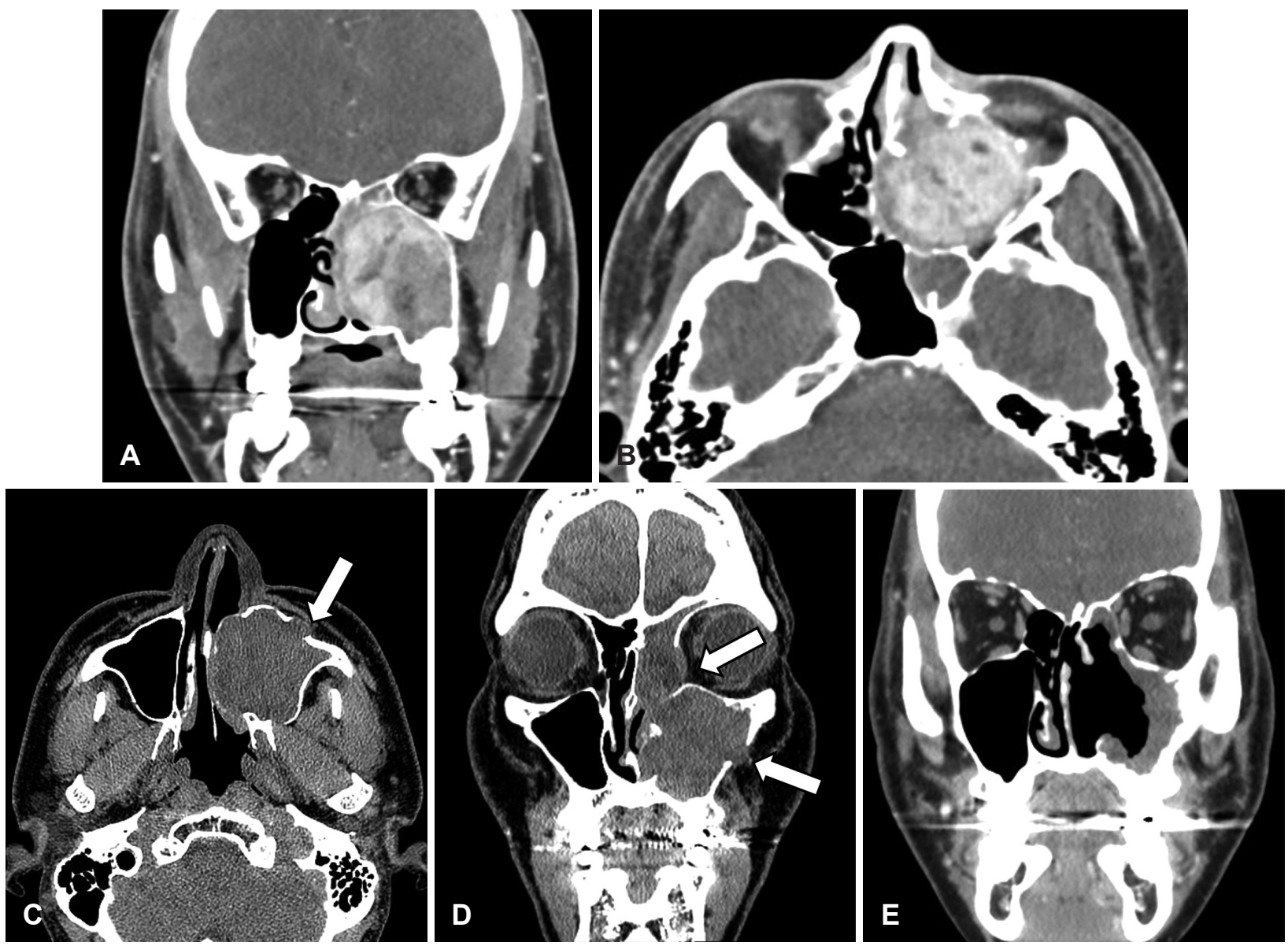

Fig. 2. Preoperative and postoperative CT scan. Enhanced CT scan (A, B): heterogeneously enhancing vascular mass occupying the left maxillary and ethmoid sinus with bony remodeling. Non-enhanced CT scan (C, D): arrows indicate bony erosion of maxillary and ethmoid sinus. Postoperative CT scan 9 months after surgery shows no presence of tumor in the maxillary sinus $(E)$. 
자기공명영상 촬영상 이 종물은 $\mathrm{T} 1$ 가중영상상 동일신호강 도를 보이며 T2 가중영상상 비균일한 고신호강도를 보였으며 조영증강 영상에서는 비균일한 증강 소견을 보였다(Fig. 3). 가장자리 증강을 보이는 점액종이나 소엽형태를 보이는 반전 성 유두종의 가능성은 낮아보이는 소견이었다. ${ }^{3)}$

외래에서 시행한 조직검사상 감별진단으로 사구맥관혈관 주위세포종(glomangiopericytoma), 뇌수막종(meningio$\mathrm{ma}$ ), 고립성 섬유종 등이 제시되었다. 따라서 악성종양의 가 능성이 배제되었기에 완전 절제를 위하여 전신마취하에 내시 경을 이용하여 상악동 내측절제술과 Caldwell-Luc 접근법 을 시행하였다. 영상검사에서 상악동과 사골동의 골파괴가 관 찰되었고, 상악동과 사골동을 거의 채울정도로 종물의 크기 가 매우 커서 Caldwell-Luc 접근법을 통해 상악동 내 종양을 제거 후 비내시경을 사용하여 구상돌기 절제 및 사골동 절제 술을 시행함과 동시에 좌측 중-하비갑개의 일부를 제거하고 상악동 내측 벽을 뒤로는 상악동 후벽, 전부는 코눈물관을 경계로 종양을 제거하였다. 종물의 크기가 매우 커서 발생 부위를 확인할 수 없었고, 수술 중 좌측 눈물관은 보존되어 있는 것 확인하였으며, 잔존 종양이 없음을 확인 후 수술 종 료하였다. 적출된 종양의 면역조직화학염색 검사에서 $\mathrm{CD} 34$, beta-catenin( $\beta$-catenin, endothelial cell marker)에 양성을 보이고 S-100에 음성을 보여 고립성 섬유종으로 진단되었다 (Fig. 4). 술 후 합병증 및 출혈 없이 퇴원하였으며 외래 추적 관찰 중이다. 현재 술후 9 개월째 재발 없이 외래 추적 관찰 중이다.

\section{고 찰}

비부비강에 발생하는 종양은 일반적으로 종양의 위치와 주 위 구조 침범 여부에 따라 다양한 증상이 나타난다. 본 증례의 신체검사상 안구돌출증은 없었고 비내시경 검사에서는 상악 동에서 발생한 종양이 중·하비갑개를 내측으로 편위시키는 양상으로 관찰되었다. 일반적인 비부비강에서 발생하는 악성 종양과는 달리 정상적인 코점막으로 덮혀있는 형태로 관찰되 었다. 따라서 이러한 소견이 코막힘과 눈물고임 증세를 유발한 다고 판단하였다.

컴퓨터단층촬영상 경계가 명확한, 부드러운 연조직 종괴 형 태로 관찰되었으나 조영제 투여 시 현저한 조영 증강을 보였으 며 사골동과 상악동의 골파괴 소견을 동반하고 있었다. 부비 강에 종괴음영이 있고 골파괴가 동반되어 있으면 먼저 악성 종양을 의심하나 때로는 양성 종양과 염증성 질환에서도 골 파괴가 동반될 수 있으며, 이때 악성종양과 감별을 요한다는 것은 잘 알려져 있다. 골전위 혹은 골팽창 소견이 보일 때는 양 성 종양이나 천천히 자라는 악성종양의 가능성을 생각해야 된 다. ${ }^{4)}$ 따라서 본 증례의 경우에도 조직검사 전에는 악성종양의 가능성을 배제할 수 없었다.

자기공명영상촬영상 경계가 명확한 증강된 종물로 나타나 며 T1 가중영상상 주변 경부 근육과 동일한 신호 강도를 보 이며 조영제 주사 후 불규칙적인 조영 증강을 보였으며 T2 가 중 영상에서는 비균일하며 주변 근육보다 높은 신호강도가 관 찰되었다. 이 소견은 일반적으로 고립성 섬유종의 자기공명영 상과 일치하였다. ${ }^{5)}$

고립성 섬유종은 조직검사로 확진할 수 있는데 일반적으로
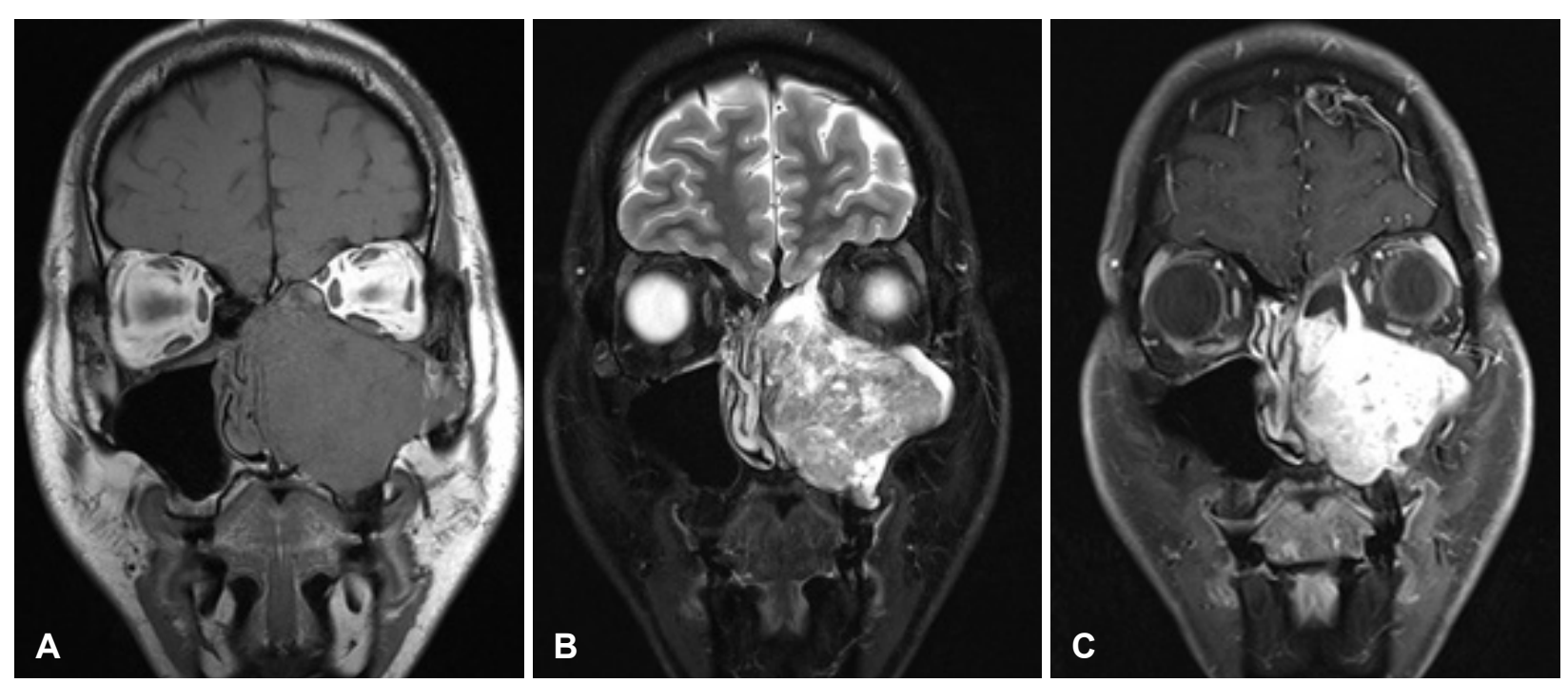

Fig. 3. MRI findings of the tumor. T1-weighted images shows Homogeneously isointense mass (A). T2-weighted images indicates heterogeneously high-signal mass (B). Contrast enhanced images shows irregularly enhancing mass (C). 

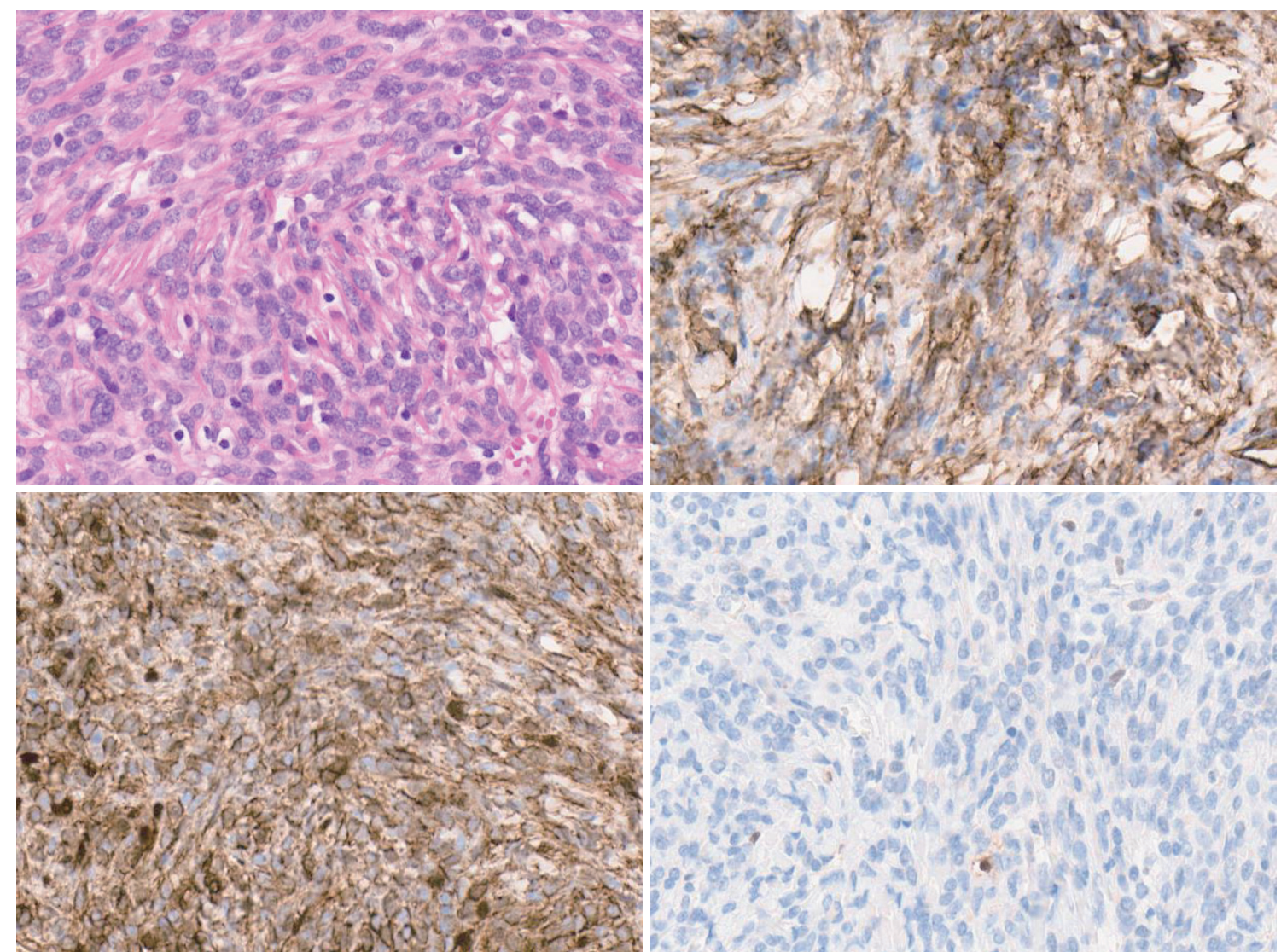

Fig. 4. Histopathologic examination of the tumor. Hematoxyline and eosin staining $(\times 200)$ showing 'patternless' pattern of spindle cells with loose fibrous stroma (A). Tumor cells are positive for CD34 (B) and $\beta$-catenin (C), and are negative for S-100 (D) on immunohistochemical staining $(\times 200)$.

캡슐에 둘러싸인 부드럽고 단단한 조직의 형태를 띄며 조직 학적으로 아교질 바탕에서 정형화 되지 않은 소위 ‘무패턴’ 패 턴을 가진 방추세포의 모양으로 보인다. 전형적으로 혈관주위 세포종과 비슷한 모양을 나타내는 풍부한 혈관분포가 존재한 다.) 면역 화학적 평가를 통해 비슷한 양상의 병리소견을 보 이는 혈관주위세포종, 혈관종, 신경초종 등과 구분할 수 있는 데, 조혈 전구 세포 표면에서 발견되는 당단백질인 $\mathrm{CD} 34$ 과 $\beta$-catenin은 고립성 섬유종에서 양성을 보여, 다른 연조직 종양을 배제하는 데 도움을 줄 수 있다. ${ }^{2)}$ 본 증례의 병리 조직 검사 소견에서 위와 같은 소견이 확인되어 최종적으로 고립 성 섬유종으로 진단할 수 있었다.

고립성 섬유종은 양성종양으로 완전절제 이후 극히 일부의 증례에서만 국소 재발이나 전이가 보고되었다. 특히 흉막 외 에서 발생한 경우 악성 양상을 보이는 경우가 더 드물다고 알 려져 있다. 조직검사상 세포과다성, 분열증가(>4 mitosis/10 $\mathrm{HPF})$, 괴사 등이 관찰되는 경우 재발의 가능성이 높고 예후 가 좋지 않다고 알려져 있다. 악성 경과를 보이는 경우에도 양 성종양과 같은 특징을 보이기 때문에 항상 악성 경과의 가능 성을 염두에 두고 장기간의 추적 관찰이 필요할 것으로 생각
된다. ${ }^{8)}$

고립성 섬유종의 치료 방법은 수술로 완전하게 절제하는 것 이 가장 적합하며, 일반적으로 부비동에 발생하는 고립성 섬 유종을 포함한 양성종양의 수술적 치료에는 다양한 접근방 법들이 시행되어 왔는데, 내시경이 도입되기 전에는 측면 비절 개술을 통하여 내측 상악절제술, 사골동 절제술 등이 시행되 었다. ${ }^{910)}$ 내시경이 이비인후과 영역에 도입된 이래 고립성 섬 유종의 절제도 내시경을 이용하여 수술적 제거를 하기 시작했 으며, 성공적인 치료 결과를 보였다. ${ }^{11,12)}$ 상악동 내 종양을 내시 경을 이용하여 제거하는 경우는 전통적인 관혈적 상악절제술 과 비슷한 정도의 재발률을 보인다고 알려져 있으며, ${ }^{12)}$ 반전성 유두종과 같은 양성의 비부비강 종물도 최근에는 내시경적 접근법이 더 낮은 재발률을 보이는 것으로 나타났다. ${ }^{13,14)}$ 고립 성 섬유종의 치료에도 내시경적 접근법이 효율적일 것으로 생 각할 수 있다.

국내에서 보고되었던 비부비동 고립성 섬유종의 2예는 우 측 비강과 사골동 등 침범한 고립성 섬유종과 좌측 비중격으 로부터 기인한 비강 내 고립성 섬유종이 각 1예씩 보고되었으 며, 모두 내시경적 접근만을 이용하여 절제하였다.9) 국외 보고 
의 경우 종양의 원발부위에 따라 내시경적 접근으로는 충분 히 절제연을 확보하기 어려운 경우에는 측면 비절개술, 안검 하부 절개 등의 외비접근법이 필요함을 제시하였다. 본 증례 에서는 상악동과 사골동의 일부 내벽에서 골파괴 소견이 동 반되었고, 종양의 크기가 매우 커서 수술 시야상에서 종양의 발생 부위를 파악하기가 불가능하였기 때문에 내시경적 내측 상악절제술과 함께 Caldwell-Luc 접근을 통해 종양의 완전 절제를 시행하였다.

고립성 섬유종은 양성 종양으로 수술을 통한 완전 절제를 하는 것이 일차적인 치료 방법이다. 하지만 비부비동과 같이 부피가 작고 복잡한 부위에 발생하거나 중요 장기에 발생하 는 경우 완전 절제가 어려울 수 있다. 또한 앞서 언급한 것과 같이 일부에서는 악성 경과를 밟는 경우가 보고되고 있으며 폐, 간, 흥벽, 복벽 등 여러 부위로의 전이가 가능하다. 악성 경 과를 보이는 경우 재발 부위에 대한 수술적 절제나 전이 부위 에 대한 방사선 치료, 항암 치료 등의 다양한 치료가 시도되었 으나 각각의 사례마다 다양한 치료 경과를 보여 아직까지 큰 효과를 보이는 치료 방법은 없으며 나쁜 예후를 보이는 것으 로 알려져 있다. ${ }^{15)}$ 따라서 고립성 섬유종의 경우 충분한 절제 연을 얻기 위한 본 증례와 같이 다양한 접근법을 통한 수술 적 절제를 시행해볼 수 있으며 수술을 시행한 후에도 악성 경 과를 염두에 둔 장기간의 추적 관찰이 중요함을 제시하고자 하였다.

\section{Acknowledgments}

None.

\section{Author Contribution}

Conceptualization: Sang Hag Lee. Data curation: Soojeong Choi. Investigation: Soojeong Choi. Resources: Sang Hag Lee. Software: Jaehyun Shim. Supervision: Kijeong Lee. Validation: Sang Hag Lee. Visualization: Soojeong Choi. Writing — original draft: Soojeong Choi. Writing — review \& editing: Sang Hag Lee.

\section{ORCID}

Sang Hag Lee

https://orcid.org/0000-0001-7698-2707

\section{REFERENCES}

1) Suh KJ. Adipose tumor, fibroblastic/myofibroblastic tumors, so- called fibrohistiocytic tumors, smooth muscle tumors, pericytic tumors and skeletal muscle tumors: An update based on the new WHO soft tissue classification. J Korean Bone Joint Tumor Soc 2008;14(1):1-9.

2) Thompson LDR, Fanburg-Smith JC. Update on select benign mesenchymal and meningothelial sinonasal tract lesions. Head Neck Pathol 2016;10(1):95-108.

3) Tatekawa H, Shimono T, Ohsawa M, Doishita S, Sakamoto S, Miki Y. Imaging features of benign mass lesions in the nasal cavity and paranasal sinuses according to the 2017 WHO classification. Jpn J Radiol 2018;36(6):361-81.

4) Park YW, Jung DK, Huh JD, Kim HJ, Chun BH, Joh YD. CT findings of nasomaxillary lesions: Differential diagnosis by adjacent bony abnormality on CT. J Korean Radiol Soc 1991;27(4):518-26.

5) Yang BT, Song ZL, Wang YZ, Dong JY, Wang ZC. Solitary fibrous tumor of the sinonasal cavity: CT and MR imaging findings. AJNR Am J Neuroradiol 2013;34(6):1248-51.

6) Smith SC, Gooding WE, Elkins M, Patel RM, Harms PW, McDaniel AS, et al. Solitary fibrous tumors of the head and neck: A multiinstitutional clinicopathologic study. Am J Surg Pathol 2017;41(12): 1642-56.

7) Mathew GA, Ashish G, Tyagi AK, Chandrashekharan R, Paul RR. Solitary fibrous tumor of nasal cavity: A case report. Iran J Otorhinolaryngol 2015;27(81):307-12.

8) Thompson LDR, Lau SK. Sinonasal tract solitary fibrous tumor: A clinicopathologic study of six cases with a comprehensive review of the literature. Head Neck Pathol 2018;12(4):471-80.

9) Ahn TJ, Bae WY, Kim SJ, Kang MJ. Solitary fibrous tumor in nasal cavity: Surgical treatment after angiographic embolization. Korean J Otorhinolaryngol-Head Neck Surg 2009;52(3):258-61.

10) Alobid I, Alós L, Blanch JL, Benítez P, Bernal-Sprekelsen M, Mullol J. Solitary fibrous tumour of the nasal cavity and paranasal sinuses. Acta Otolaryngol 2003;123(1):71-4.

11) Bowe SN, Wakely PE Jr, Ozer E. Head and neck solitary fibrous tumors: Diagnostic and therapeutic challenges. Laryngoscope 2012; 122(8):1748-55.

12) Kodama S, Fujita K, Suzuki M. Solitary fibrous tumor in the maxillary sinus treated by endoscopic medial maxillectomy. Auris Nasus Larynx 2009;36(1):100-3.

13) Lund VJ. Optimum management of inverted papilloma. J Laryngol Otol 2000;114(3):194-7.

14) Waitz G, Wigand ME. Results of endoscopic sinus surgery for the treatment of inverted papillomas. Laryngoscope 1992;102(8):91722.

15) Dozier J, Jameel Z, McCain DA, Hassoun P, Bamboat ZM. Massive malignant solitary fibrous tumor arising from the bladder serosa: A case report. J Med Case Rep 2015;9:46. 